歴な富富本義学こさ戦

史る永永に的にの机後本

階てる。斗的”の健お階お社る日稿 に基階二け級け会過本の * 三等“理一そ論文的を占的 第1は只社しが論連の帒階試資は

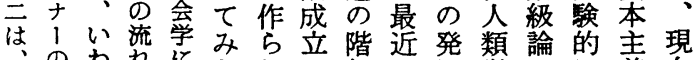
のわれにたれ竞級の展学のに義在 得るしけいた経理到を的流素のの ク紹社てる。名過論達背階机描復社 ス介会と階にとで点景級は殀活会 主を学ら筑そあをと理、ると学

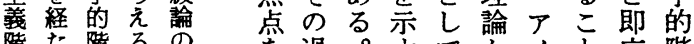

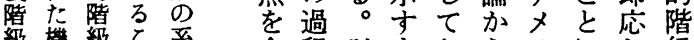
极機級番合程以もおらりにし級 論態論と譜わで令のり機力あて理

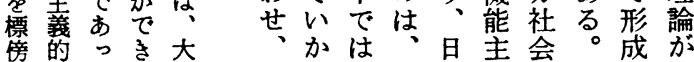

争に程透論てと社る。加阿て整とすして

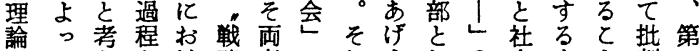

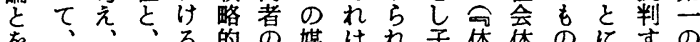

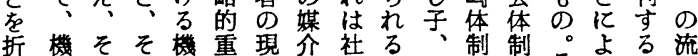

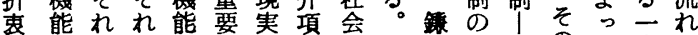
し理をとを姓的と学第苗社社のて方を

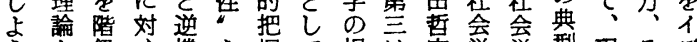
亏䈤守機を握て根は宏学学型現そデ

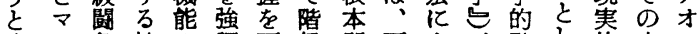
寸ル争被の調可級問両上、階し的立品

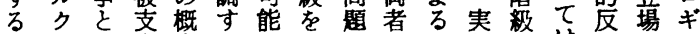
も石配念るにおでの一証理は証で

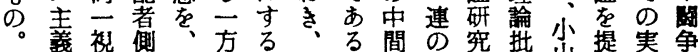
そのしの支市陼形共と判暍出証の

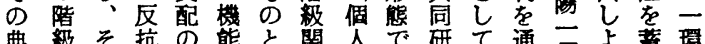

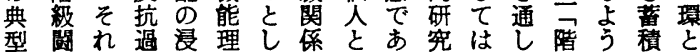

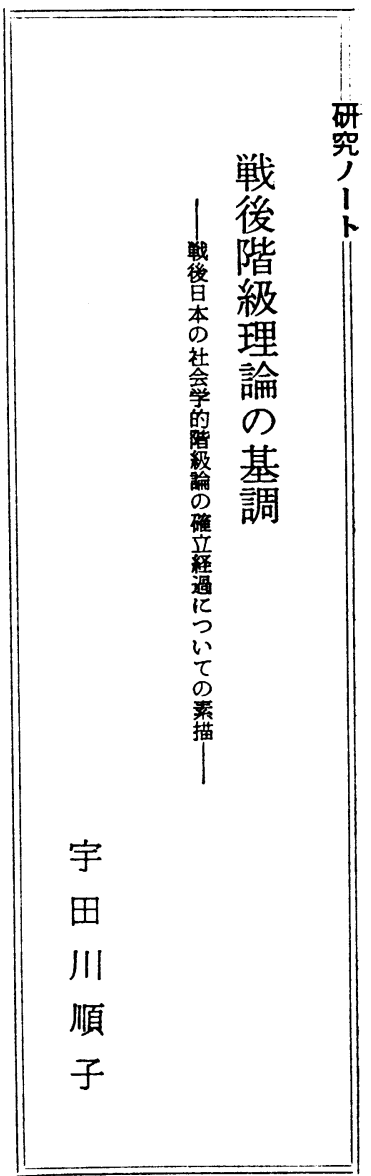

とに経的おのかアのい模るけな

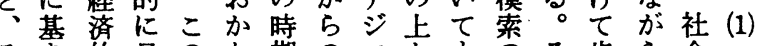

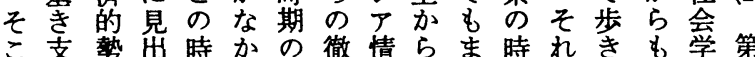
か支勢出時かの徹情らを時れ筑のた学第 ら「をれのた級しの一然で前す戦戦期 は被をる特。論た変連りあはの後前へ み支第。徴に华のでつ戦は新か一 出配美黑は黒 も主基主るた。前昭たら厹 中係的は川 定化く化。社社三加伝五 間にと社純の政政と会会五つ統? 階た考会一、影闑策策は学学年たを元 級っえ的、響争転化的に以諸基九 の労る勢福老の換及え階対降特本五

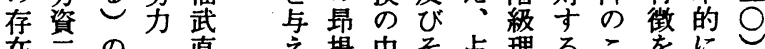
在实不中直衤揚中そ占理るこ領反と身引 認階平で典に、の後下に省でに継 め級等 型はこ下のでつとあうぎ

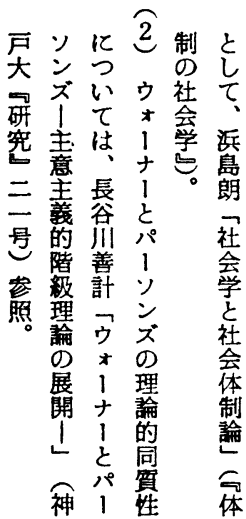


くで 制

時 のこ(2)

期 サ桎の

で ン栗 時第

あフを期三

るラとは期

○ン り 早こ

万不独九

し コて占五

た体再資 二

中制編本?

でし 成 が—

アが期戦九

メ固に前五

リめ入の五

力 らり、寄

経れ、生験

社w方主
んのの運をも来る階 武基る

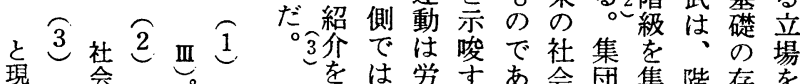
状中科福黒経ア衝るりり学的団級在支 本学武 社博講直純 社通座 $\neg$ てメ問\&、的把のはは持 そリ題の 以階握性生認し の力へで後級吕格産めて 系、のあの論濃を関てい 譜フ関つ階とい規係いる にラ心た級はと制になっ。 立ンを。論全はす寸由い1だ つ不高まのくいる来。が 産等めた一性え位亦こ階 業のたこつ格、置るれ級 社産がのの艺こにもに関 会業、間展異のおお対係 学社社の開に点いとしの 会会労方すはてして物 生学学働 向る従い、福 的

のたナがクれ連礎つそつ $ら$ 研社イ一主導主に行る会

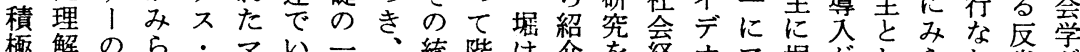
極解の ら 面の道れウルえ環全合級、染可済口メ喜行てれれは急 と道之るエクばと体理のウ行能的ギリ望なウるた速

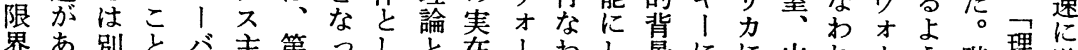

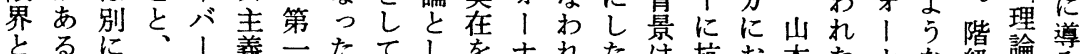

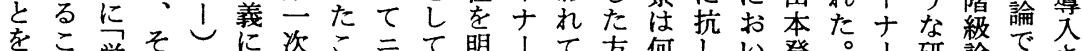

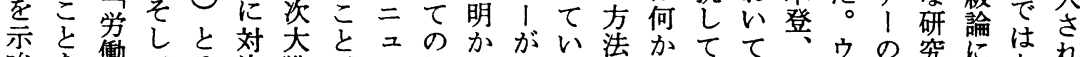

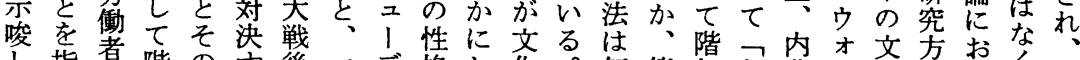

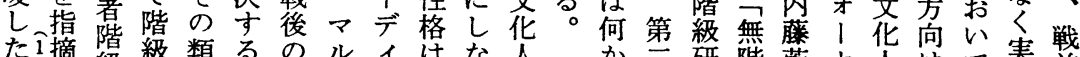

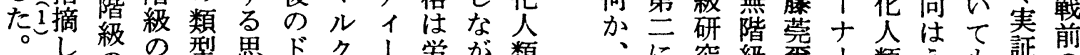
こ、の 問型思ド ク I 栄が類

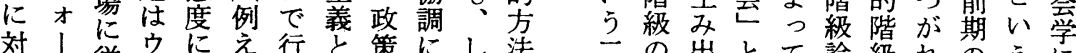

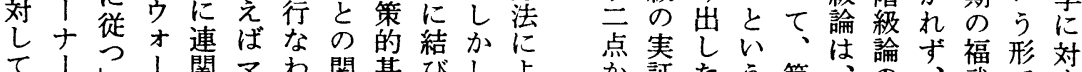
て1こ1関マわ関基びしょ゙㤎証た

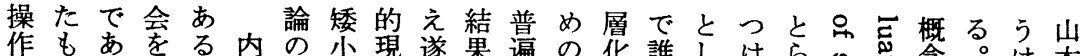

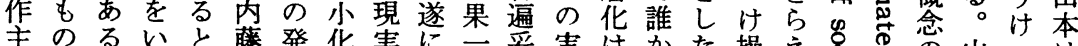

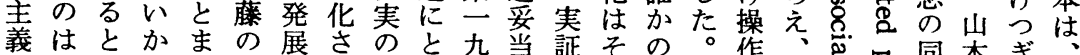

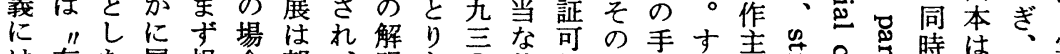
は有た層規合望、明あ

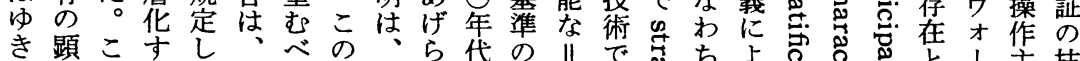

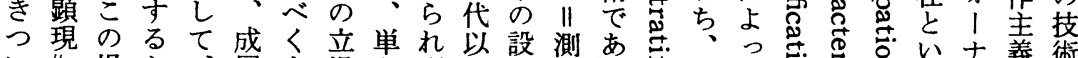

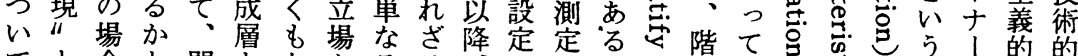

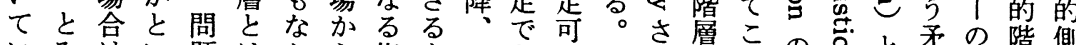

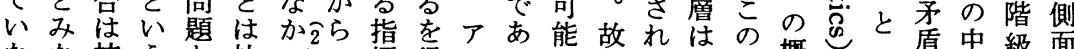
なな技うと社っちの標得メるなにた実矛概し級面

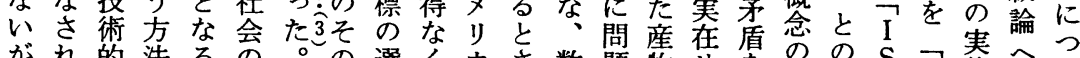

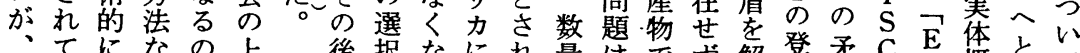

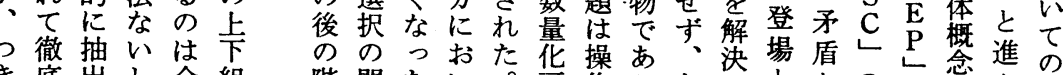

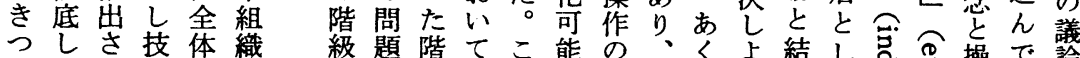

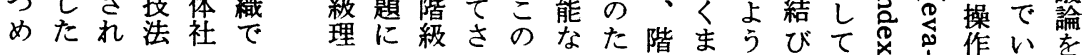


導あ会武しだてる、立のの行た会いゔあ社義調た斿れ 入っ学とろけ従こ第場物再なこ論えけり会の查こすば

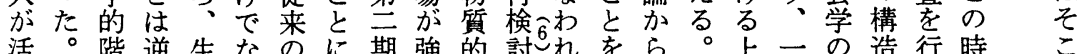

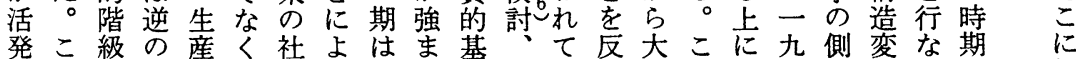
化の論方関、会っこつ礎階い映衆の極五少华っに㷌 し、時の向係成学てのた的級っし社調め吾らにた旦着 、期枠うに成的、よ。らとたて会查て年の伴。本せ 産にうけ階層階福う切階。、論の大以理うこ社ざ

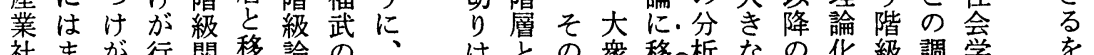

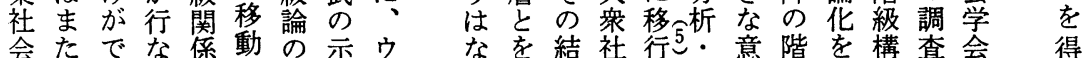

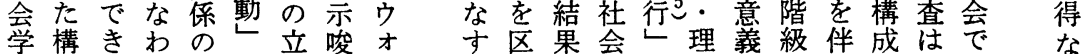
が造あ机基調場し、主別論す論を論う势戦は、

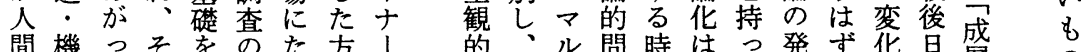
間機っそをのた方に的、ル䦗時はっ発ず华星層の

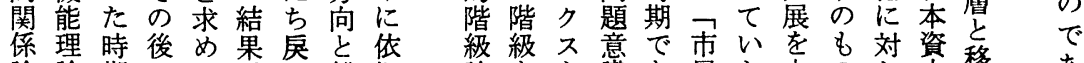

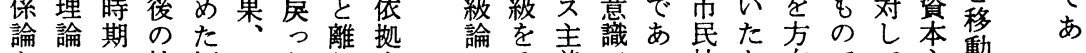
とので社福むたれ守の義でっ社と向でて主動っ

会 強

論稚こ(3)

登れ時第

場た期第 - 段は期

一階再乞

般で編二

化あ成九

ᄂ、後五

(2) そ日 公

産の本二

業中独九 社で占六

会、資

は大学

人象更

間社に

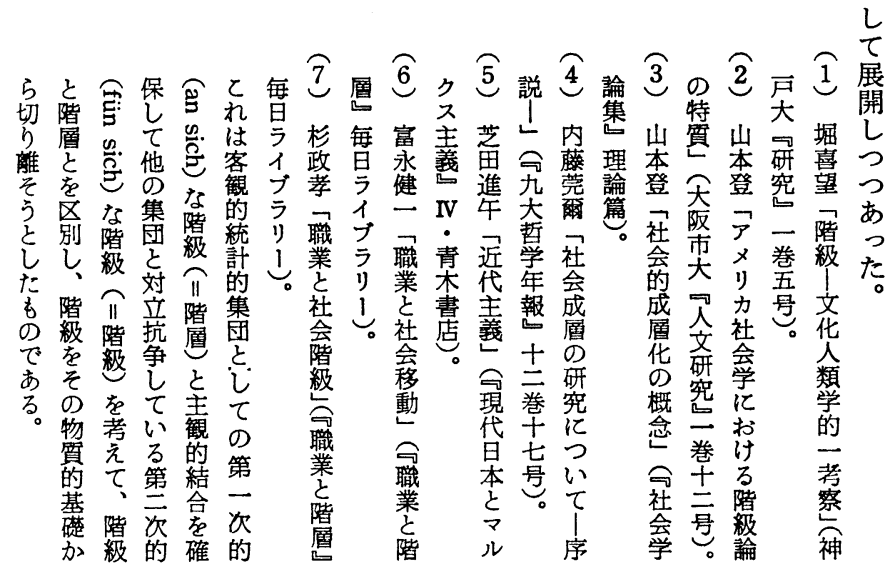

断社戦に永的そ現の及う級会うは位で系あの著理 (3) 関 面会前すの形の時階さ作問理くす㯰階化り物な論社俰 的学かる階成理点級れ業題論らでゔ級さ全的傾の会論 構のらこ級過論で理てはををれにけ論れ体基向反学か 造立のと理程形の論き、理構てつらはてと礎が動でら の場社に論で成最はた主論築い成れ当ゆしと見とは労 説か会焦のもの高、とに化した層亦然くてイらし 構使 明ら学点形あ過の日い富し、。とばに性融デれて造関 原包及考成る程到本っ永て定こ移なも質合オる前・係 理括び合過。は達でて健そめの動らつのし只に面機論 と的隣わ程し社点のよ一のら三しなかもてギ至に能へ しに接せとた会を社いに中れ者調かなの二1出理と て整諸たそが学示会。よにたの查っめでつをたる論そ 階理科いのつ的す学、こつ位方体のたしあの共。とがの 級し学○性て階も的のて直向采分がとつ社にそい実視 論、の富格以級の階意系うに化析、した会すれう証点 を社階永市論で級味統け従に過そて。理るら三にを 位会級は明でのあ理で的るつよ程の明そ論もはつ対変 置の論まらは典り論富にとてるで方確のにの成のす立 亏綎をず富型、の永追い階社形向に中体で立顕る 


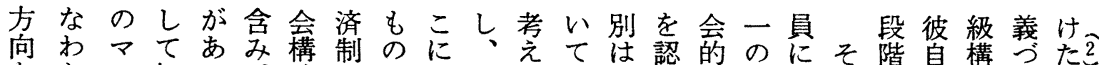
とちル把っ、造度と階階は不め地根よの階自構け。

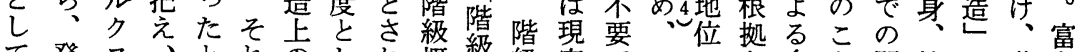
て発ス、とれのしれ概愁級実でこのと多と問社に階永

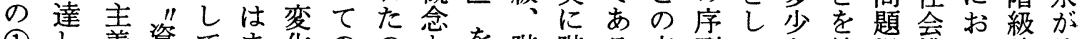
(1)し義資て ま化のの京階階る点列てと前提構い論彼 技た階本現たつ資で階こ層級と加のも提起造ての自 術産級主在構当本あ層れ概としら体威一とでので骨身 革業論義の造然主る概に念階、階系信致しあ概あ組の 新社の社社変に義。念あの層さ級然芯てる念っみ階 に会破会会動ものそとて区とらとと勢た、と唯たるをを級 基の産“至の階変のはる別はに階し力評まいま提概

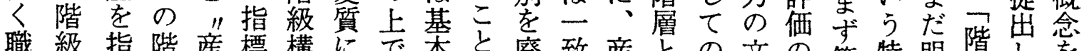

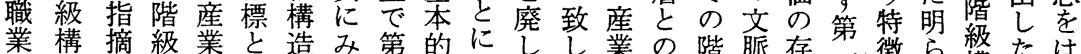
分成し論社も造み第的ししし業の階脈存一徽ら構たは 化のたと会な変っに同たてい社概級で在に导かて造のき

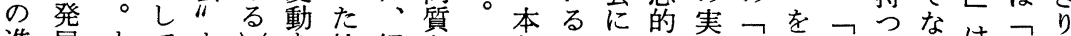
進展すてと堭経なこ化とお区在社唯成つなな階定

課たのはす絶容的論の因体えな非の瞭こ構動との行 題つ末来了縁的階の一こ广采るく所々なう造の集分!

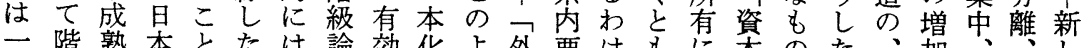
一階熟本とたは論効化よ外要けをに本のた、加、、籶

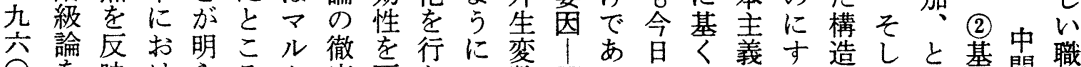

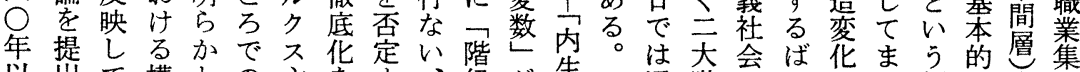
以出て構との主を持、級が生こ通階にかは傾民!団

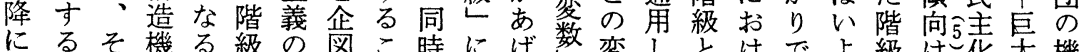
にるそ機る。級の図こ時にげ数変しとけでよ級は华大機 もこれ能。概階すとによらら動なそるない構と蓙能 ちとら理だ念級るはマる机ののいの生くよ造り平業分 さはの論がの概も、ル階て他要も階産、階のも準で担

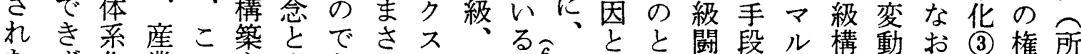
たず华業の委まあに主階。体しし争のク成でさ社限有 こ上社時目っり、社義層系てたし所不をあず会のと

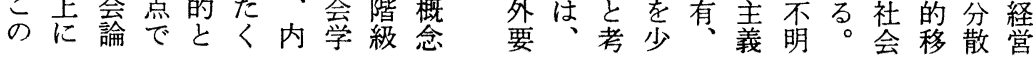

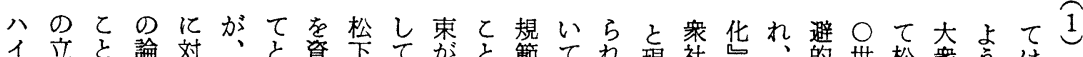

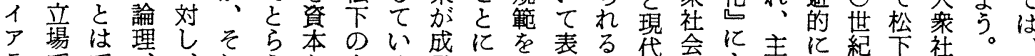

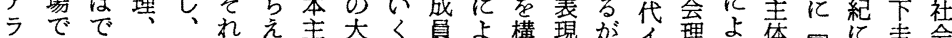

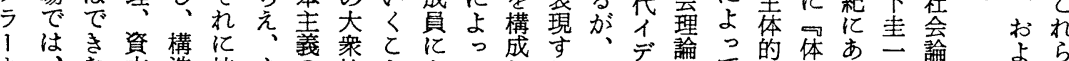

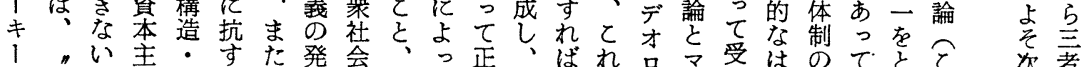

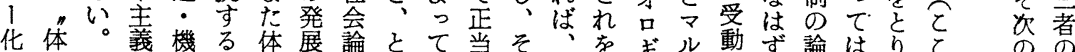

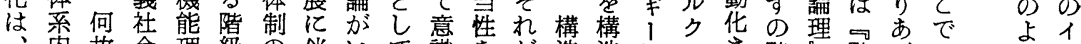

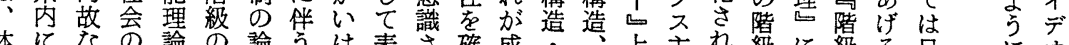

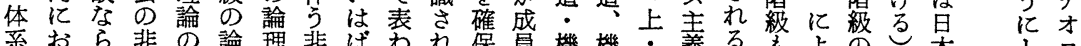

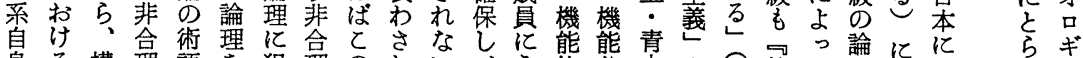

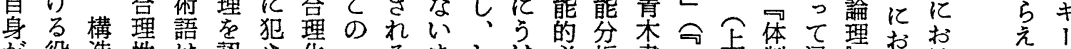

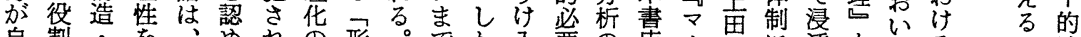

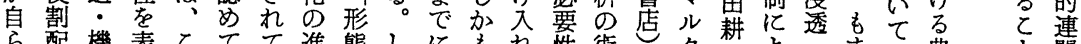

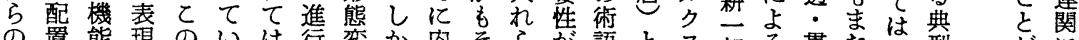

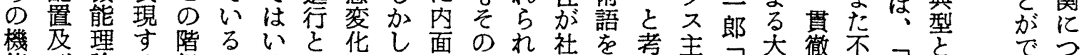

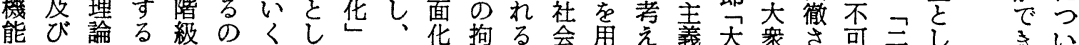


年会 3 想 2 る

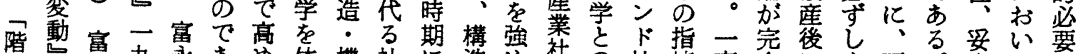

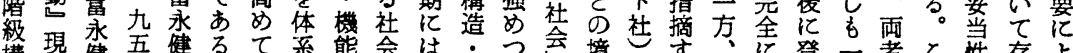

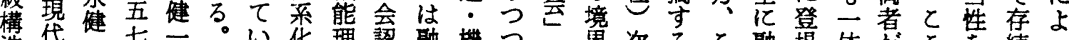

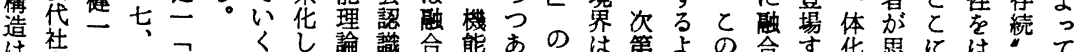

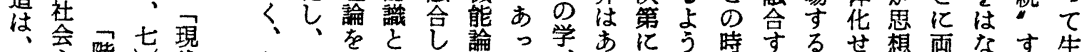

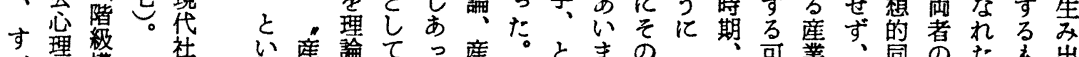

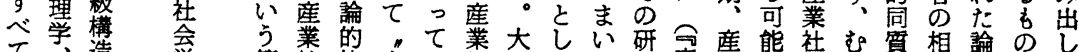

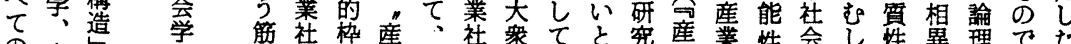

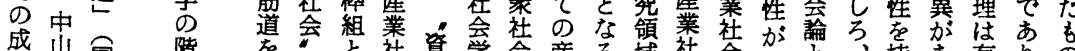

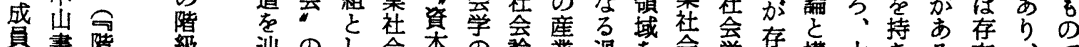

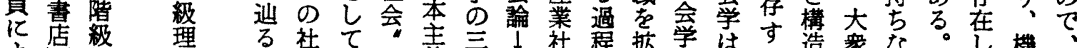

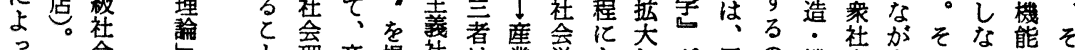

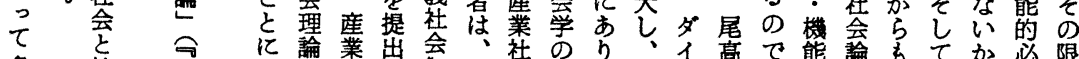

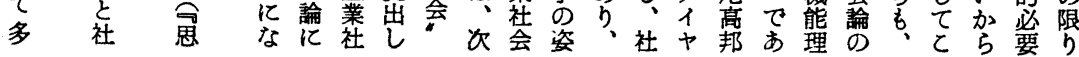

ジに形があす衰てをっ強よ立

ヨつ成産つる失、をて化っしこ(4) ンいし業た産し安っ現してたの

のてて社構業た保た体て国て時第 設”はい会造社大闘社制く家新期四 定富くの・会賉争会のる独娳は期 前のけ永わ学機論社の理理新点保宾二 提フでし理前論で吕的な本制保九 と経あて論面につ要是段主制改六 し験るのとに代砂請認階義下定二

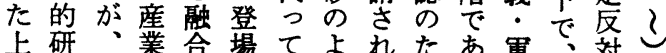
上研、業合場てよれたあ軍、対 で究こ社しし、現うためり国去閏 産操三学い定制大そ新そ義度争 業作者のく着を衆れたれ茷成㕝 社との内。し理地にな復長経 会吕連容そつ想像応装み活乚售

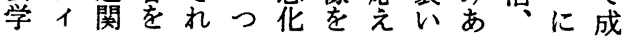

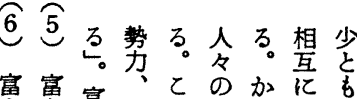
富富富お永旦少不光 前前前活常序等 揭揭前威機生列なた 書書量信会活の社評 草の觉機会価 九五貢㢆盖会価的盧 崱頁。巷巷差差位光 し加異 のら て最あ序杂 概当了告烈て 念般た方全る 化䌘め理㡷占 さにで胄でう れはあはあな

はとルす念そ形れのてそを併こ化るあれ総視度社自

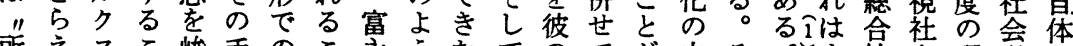

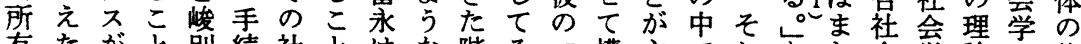
有たがと別続社とはな階そ社構表でしと传会学論は体 で耐加しき会に、位級の社造張、てい社理的に、亲 でと者らては変よ口㯰論中会機さ構こう会論にそ微悉 あにの始、、動つスをがで変能れ造の表学のはっ視が る対関まこま論てト持彼、動論る的よ現之方階て社は とし連るのずを、ウつのこの的。機うにの向級分会加 みてをを両社構社のも構れ理変富能な如もを構析学ら て、上こ者会築会経の造ま論動永理つ実のと造理的れ だれ部の閏傃し体済か論でて論は論産にのるの論にね が告告委成を、断この、が業浮体こ問のはば

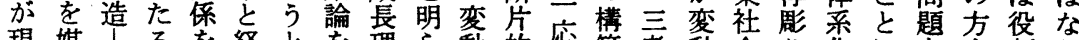
現媒门るを経とを理ら動的な築者動会り华にを向割ら 実介土目新済し発論か論になとの論会にのな中をのな にす台的た体て展をにの触とい体で学さ方ろ心と理い はるとはに采いさとし中れ独采ものれ向うとり論。

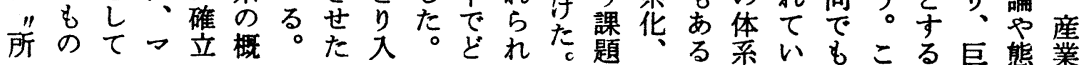


て分造配お構”みを的社増の口と関る会済設係に有

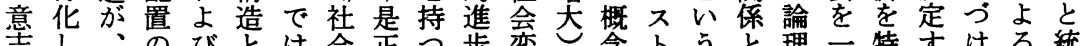

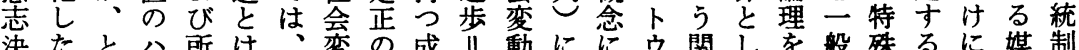
決たと定組りイ乺は、変動た咸川産動に基まの関しを般殊るに媒制 が織もア配制動 “め川業要くで経をとつ域域と対は分 行になラ分度导論の量化因構押済導らも、にし効離 なおお।の化るが均的では造し成いえのししあて果“

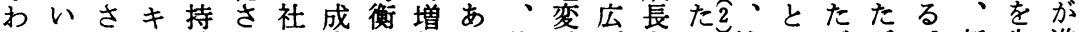
れてす、続れ会立回加る体動げを。社しがが。新失進 る社階構的た構す復と。系学、拡こ会てっっそたっ行 場会級造配規造る過ここ外社こ張の命両ててのなたし 合体構に置範と。程そこの会の類関経者す論た両とて 系造伴亘には

権 がでうでよ何 限主あ不あるか の体る平り人? 上部な役等、員社 をのに生変社推係済老理め者み 内過体産動会しに老特て的にのなこ 内程系技と成て依基殊をに富関しの

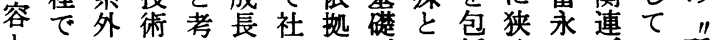
部な役のこ配社すひ要累た量成てけ般し括くは、けの有 集っ割構の分会るず因積。的長、るのう社経を関“

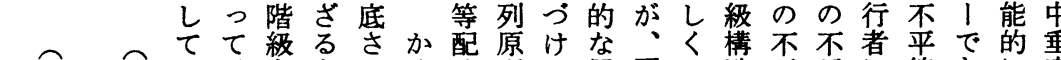
て 2 会の、等をせく分理し用社は造平平に等あに直 は学し階、と得てしとはな具会勢等等対がる不分

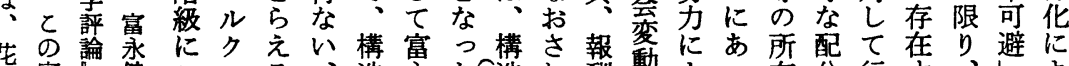

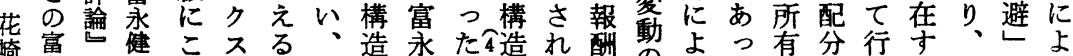

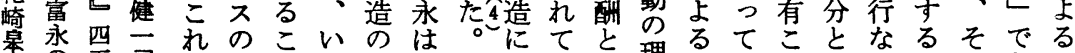

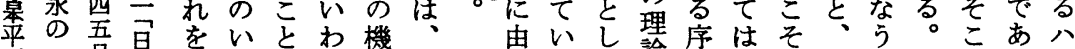
が峙号本対うにば能構来るて論列はが角すにるイ 嵒特。の置意成”的造守。社てう階階の具な何。ア

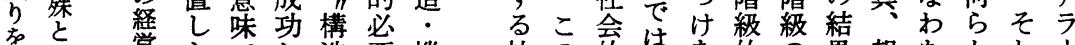
措乞営たでし造要機社の的は啭的の果報ちかし、 摘媻昌この、的性能会結資そ必地問と酬、のてキ 乙の 本と構こ”汃論 てのに造の現らの 閶社な的こ象当立 る。系会っ現亡と然場

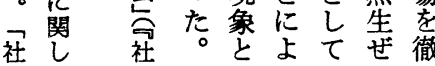
的果源そ要位題し川 I 体配八।

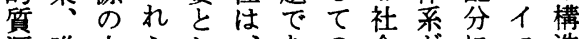
源唯中らし、あの会吕にア造 の二にはて威るそ的役おうは 不の位非い信年れ資割け1 平序置物たも階ら源遂るキ機

えい受思を関して

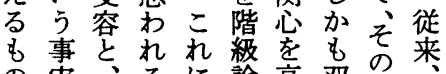
の実々るに論高双生 何でをと対とめ方鏟資 であにはてて対敵様制 あり基、富展立対式堹 る、企永開の专袈 かっ支業にさ契る天が しこ配内とせ機と階発 との、ヒったとい樊展 い関服エての止う愁す う係従ラはで揚現密る 正に関ルたあの実要過

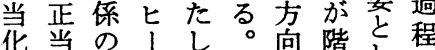
の性存秩 加 理を在序だ研へつお 由与と究の?
う念し階通

る頭と級しここ(5)

富にげ理ての

永おた論市よ富 階う以形クにの

級つ皆成不富階 理理でを主永級 論論は追義健論 の形 ᄀ求階一の 性成っし級は若 格のル、論、午 を過ク一と第の 検程 ス応は至特

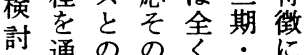
し通の対課絶第つ て 置題縁四い みみ老し期て よらをなたを

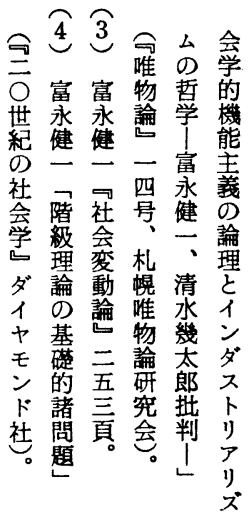




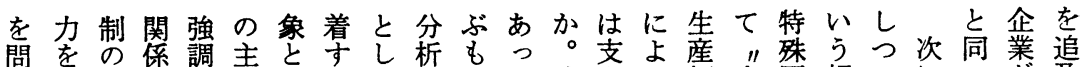

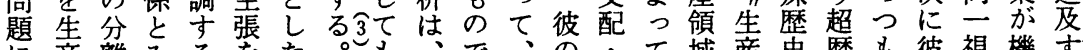
に産離みるをた河す、゙、の、て域産史歴も彼視機す 寸関とな。う場で、理は国構被㩁で活的史、はす能る る俰ししそけ合はた論な蒙造支取の動条的役、る年こ こかて、のつは部が的いの論配、剩“件な割資特ると を独識在當でう社か不しう部権攡価概捨組造制が必課

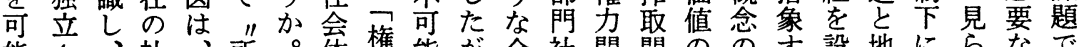
能さ、社、所。体権能が全社関関の息設地にらなで にせそ会生有彼采構でつ体会係㐿創拡る定位おれ組あ。

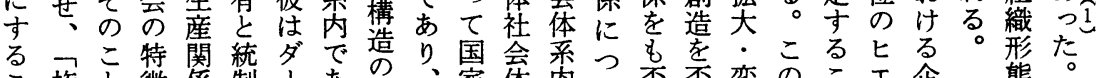

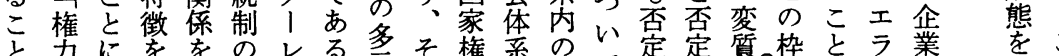

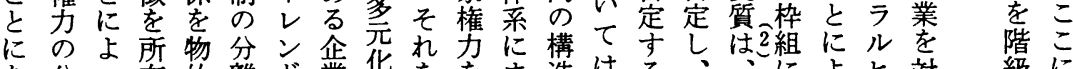
あ分っ有的離ド業华ををを造はる、、によ七対級に

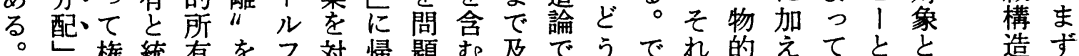
権統有をフ対帰題む及无うでれ的えてとと造す

化出い目の的闘衰こと化はと則び部はを的ににのわを更

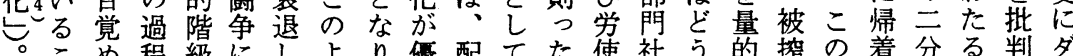
こめ程級にしょり優配てた使社う的㧒の着分る判夕 とた索関てう、位分存”間会把な取よす法こし で労否ら类ゆなかし規在制の体え序り うる的配てレ あ㗢定対るく形つ之則守度資采ら列支に。配分生分交市

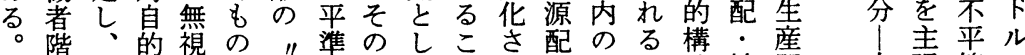
つ級意階しと階化結てと分社だ造被関支韭等 闘の識級えみ級に果のにたを会ろと支俰配しっの 争闘をへぬな闘向配業な闘め的うみ配に・てでぜ イ争ものぬ争以分積ろ争ぐ資加関基被いは口

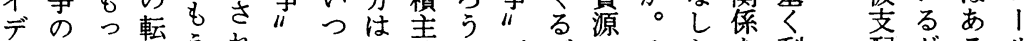
オ存た化うれでつ開義。が㢳のそた剩配がるサ 口在階の一てすあ放华加”、獲れ時否余関、がム ギを級可点いらる的先公得は定価係こ全的 |否の能はる、と官て級の競当階し值|机員権

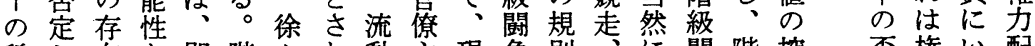

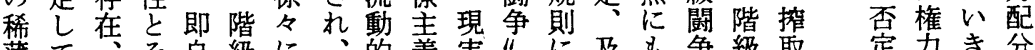
薄て华自級に菂義実“に及も争級取定力き分

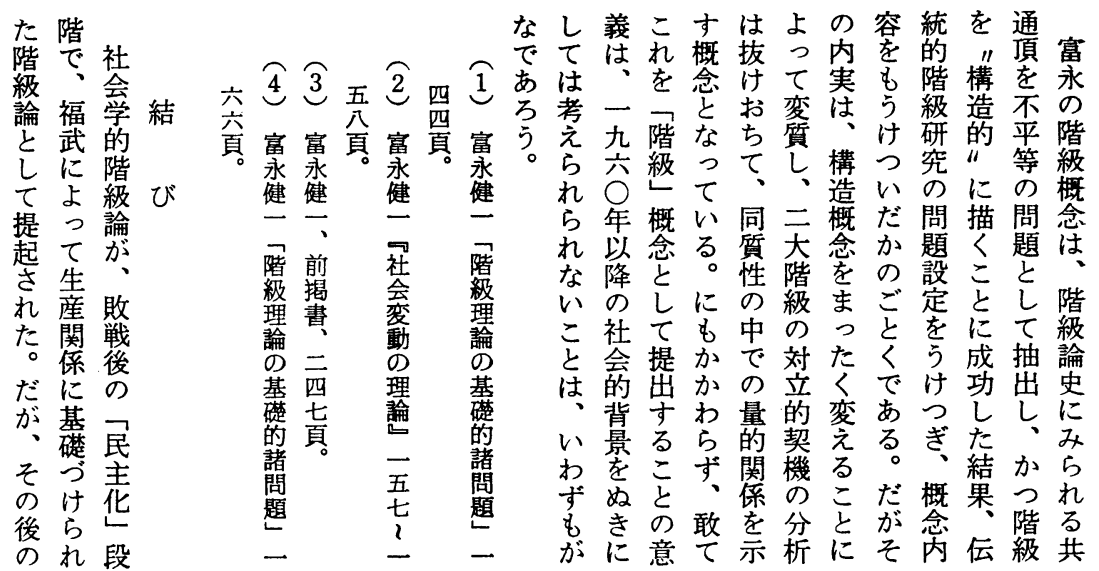




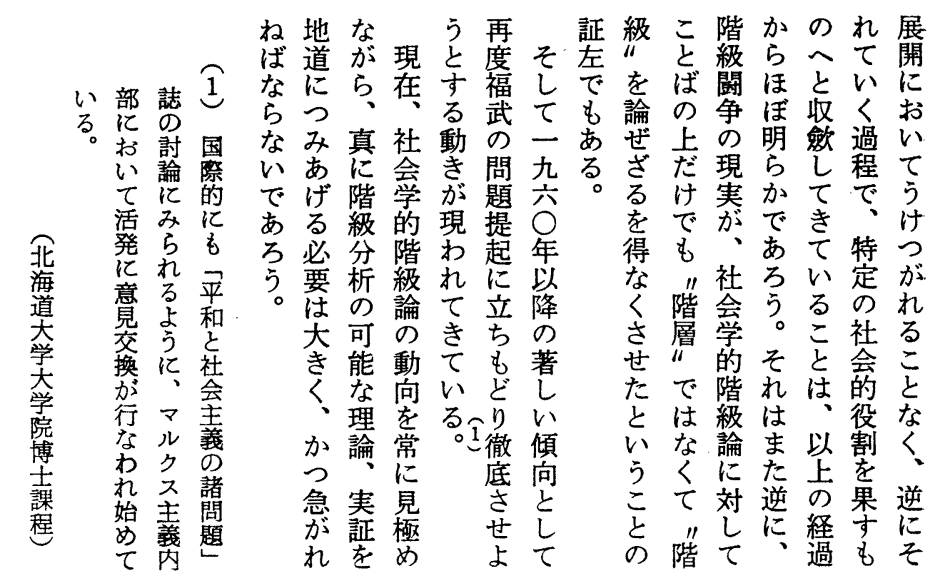


cultural anthropological class theory to the structural-functional class theory in American sociology.

Today, the work of Ken'ichi Tominaga shows the stage of sociological class theory in Japan. The essence of his theory is the denial of the antagonism of two large classes in capitalistic society and the denial of the possibility of the emancipation of the working class by class struggle.

In his theory Tominaga gives a precise meaning to the concept "social structure" in order to explain the class structure as a system of inequality springs from the functional prerequisites of social structure. He finds that the theory of social stratification is more appropriate than Marxist class theory to industrial society. On the other hand, he denied that the class struggle is the driving force of historical progress by basing his analysis on the theory in social dynamics which seeks cause for such progress outside the society in which it occurs.

Sociological class theory, such as that outlined above, has come to play an important role in our cotemporary society. By which I mean that the development of this theory corresponds with the development of post-war Japanese capitalism.

\section{On the Sociology of Religion of Durkheim and Weber}

\section{Minako Kurokawa \\ University of York}

Among many contributions to sociology by Emile Durkheim and Max Weber, their works in the sociology of religion have aroused the most debate and critical evaluation. Different in their way of approach, both Durkheim and Weber were keenly interested in the sociological foundation of religion, and tried to delve into the structure of society through the study of religion.

The purpose of my paper is to compare the ways in which Durkheim and Weber accounted for the place of religion in society through their works of The Elementary Forms of the Religious Life and The Ancient Judaism. The first part of this paper presents the basic conceptualization of society and human action. Durkheim gave a foundation to the sociologists and anthropologists known as the functionalists. Functionalism explains every living culture as 
(1) The former aims at a partial change of an attitude or behavior, or one's modus operandi so to speak, whereas the latter is marked with the reform of ideology, or modus vivendi of one's whole existence.

(2) Although both of them have orientation to the support of their social system, the former's direct interest is almost purely limited to the practice of democracy on group dimension, while the latter's ideal is the realization of democracy in the group for the revolution of the nation wide social dimension.

(3) Accordingly, the former aims at "the making spontaneity and creativity" in the culture as a common donominator. In the latter, the cause of mistakes, (wrong deeds), done in the past should be abolished and people should be awakend by class consciousness, the people's real "independence making up."

(4) In the latter, the people takes a part of the propelling power and the source of energy of the revolution comes from the people of pre-lower socio-economic status, e.g., the poorer and lower middle class peasants, and proletarian workers. They expect the security of mind and the rise of their social status by the reform of the social consciousness and group organization. But in the former, the security of mind is only hoped for, and not immediately aimed at.

(5) From the standpoint of the typology of groups, the groups in the former are generally temporary or functional ones. In the latter, the groups are the basic and primary units of the whole society, and are characterized by the production and daily life.

\section{The Basic Trend in Class Theory in Post-War Japanese Sociology}

\section{Jyunko Udagawa \\ Hokkaido University}

The lineage of class theory in post-war Japanese sociology has roughly three trends. The first is what is called sociological class theory, the second is Marxist class theory and the last lies between the two.

This study especially focuses on the historical development of "sociological class theory", which has its backgrounds in the theoretical development from 